Supporting Information

\title{
Selenium Heterocyclic Electron Acceptor with Small Urbach Energy for As-Cast
}

\section{High-Performance Organic Solar Cells}

Zhenzhen Zhang ${ }^{\dagger, \neq}$, , Yawen $\mathrm{Li}^{+}, \&$, Guilong Cai ${ }^{\perp}$, Yihang Zhang ${ }^{\dagger}$, Xinhui Lu ${ }^{\perp}$, Yuze Lin ${ }^{\dagger, *}$

${ }^{\dagger}$ Beijing National Laboratory for Molecular Sciences, CAS Key Laboratory of Organic Solids, Institute of Chemistry, Chinese Academy of Sciences, Beijing 100190, China.

$\$$ University of Chinese Academy of Sciences, Beijing 100049, China

${ }^{\perp}$ Department of Physics, The Chinese University of Hong Kong, New Territories 999077, Hong Kong, China

\& These authors contribute equally to this work.

*Correspondence to Y. Lin, Email: linyz@iccas.ac.cn

\section{Materials and Synthesis.}

Unless stated otherwise, all the chemical reagents and solvents were obtained commercially and were used without further purification. Compound $\mathbf{1}$ and 2-(5, 6-difluoro-3-oxo-2,3-dihydro-1H-inden-1-ylidene) malononitrile were purchased from Hyper, Inc. D18 was purchased from Solarmer Materials Inc., and Y6 and PNDIT-F3N-Br were purchased from eFlexPV Ltd.. PDINN was synthesized according to the literature procedures. $^{1}$ 

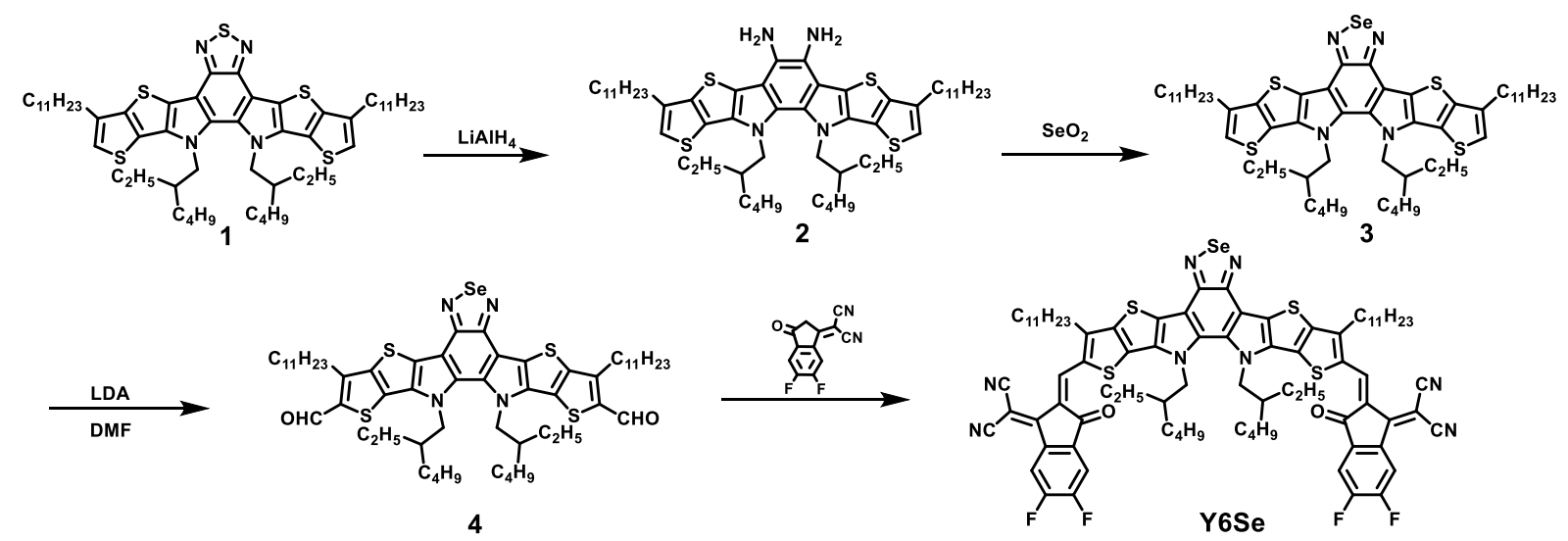

Scheme S1. Synthetic route of Y6Se.

\section{Synthesis of compound 3.}

Compound 1 (1.00 g, $1.03 \mathrm{mmol}), \mathrm{LiAlH}_{4}(0.78 \mathrm{~g}, 20.60 \mathrm{mmol})$ and THF $(20 \mathrm{~mL})$ were added into a $50 \mathrm{~mL}$ flask. The result mixture was stirred at $75{ }^{\circ} \mathrm{C}$ for $14 \mathrm{~h}$ under nitrogen. After cooling to room temperature, the mixture was extracted with dichloromethane (DCM), dried with anhydrous $\mathrm{Na}_{2} \mathrm{SO}_{4}$, filtered and concentrated under reduced pressure. Compound 2 was obtained without further purification. To a solution of compound 2 in mixing solvent THF $(25 \mathrm{~mL})$ and absolute ethanol $(25 \mathrm{~mL})$ was added the hot water solution of selenium dioxide $(0.29 \mathrm{~g}, 2.58 \mathrm{mmol})$. The mixture solution was stirred at $70{ }^{\circ} \mathrm{C}$ for $3 \mathrm{~h}$ under nitrogen. After cooling to room temperature, the mixture was extracted with DCM. The resulting crude compound was purified by silica gel column using a mixture of petroleum ether (PE): DCM $(20: 1, v / v)$ as the eluent to give compound 3 as red solid $(0.25 \mathrm{~g}, 24 \%) .{ }^{1} \mathrm{H}$ NMR $(300 \mathrm{MHz}$, $\left.\mathrm{CDCl}_{3}\right) \delta 6.92(\mathrm{~s}, 2 \mathrm{H}), 4.50-4.46(\mathrm{~m}, 4 \mathrm{H}), 2.74(\mathrm{t}, J=7.7 \mathrm{~Hz}, 4 \mathrm{H}), 1.98-1.96(\mathrm{~m}, 2 \mathrm{H}), 1.78$ $(\mathrm{dd}, J=5.6,1.5 \mathrm{~Hz}, 4 \mathrm{H}), 1.48-1.10(\mathrm{~d}, \mathrm{~J}=2.4 \mathrm{~Hz}, 36 \mathrm{H}), 0.98-0.78(\mathrm{~m}, 18 \mathrm{H}), 0.61-0.53(\mathrm{~m}$, 12H). MS (MALDI-TOF) m/z calcd. for $\left(\mathrm{C}_{56} \mathrm{H}_{82} \mathrm{~N}_{4} \mathrm{~S}_{4} \mathrm{Se}\right)$ : 1018.46. Found: 1018.6.

\section{Synthesis of compound 4.}

To a solution of compound $3(0.20 \mathrm{~g}, 0.19 \mathrm{mmol})$ in anhydrous THF $(20 \mathrm{~mL})$ was added 
Lithium diisopropylamide ( $2 \mathrm{M}$ in THF/hexane, $0.48 \mathrm{mmol}$ ) dropwise at $-78{ }^{\circ} \mathrm{C}$ under argon. The reaction mixture was stirred at $-78{ }^{\circ} \mathrm{C}$ for $1 \mathrm{~h}$, and then anhydrous DMF $(0.05 \mathrm{~mL})$ was added. The mixture was stirred $5 \mathrm{~h}$ at room temperature. Brine was added and the mixture was extracted with DCM. The organic phase was evaporated and the residue was purified by silica gel column using a mixture of PE : DCM $(1: 1, v / v)$ as the eluent to give 4 as orange solid (92 mg, 45\%). ${ }^{1} \mathrm{H}$ NMR (300 MHz, $\left.\mathrm{CDCl}_{3}\right) \delta 10.13(\mathrm{~s}, 2 \mathrm{H}), 4.57(\mathrm{t}, J=11.5 \mathrm{~Hz}, 4 \mathrm{H}), 3.19(\mathrm{t}, J=$ $7.7 \mathrm{~Hz}, 4 \mathrm{H}), 2.03-1.83(\mathrm{~m}, 6 \mathrm{H}), 1.48-1.17(\mathrm{~m}, 36 \mathrm{H}), 1.00(\mathrm{dd}, J=20.5,13.7 \mathrm{~Hz}, 18 \mathrm{H})$, $0.65(\mathrm{dt}, J=14.1,7.0 \mathrm{~Hz}, 12 \mathrm{H}) .{ }^{13} \mathrm{C} \mathrm{NMR}\left(101 \mathrm{MHz}, \mathrm{CDCl}_{3}\right) \delta 181.72$ (s), 153.37 (s), 146.87 (s), 143.19 (s), 136.89 (s), 136.48 (s), 132.82 (s), 129.64 (s), 114.33 (s), 77.48 - 76.88 (m), 76.70 (s), 55.15 (s), 40.18 (s), 31.91 (s), 30.33 (s), 29.73 - 29.10 (m), 28.19 (s), 27.64 (s), 23.14 (s), 22.70 (d, $J=2.9 \mathrm{~Hz}), 14.11$ (s), 13.67 (s), 10.09 (s). MS (MALDI-TOF) m/z calcd. for $\left(\mathrm{C}_{56} \mathrm{H}_{82} \mathrm{~N}_{4} \mathrm{O}_{2} \mathrm{~S}_{4} \mathrm{Se}\right)$ : 1074.45 . Found: 1076.8 .

\section{Synthesis of compound Y6Se.}

To a solution of compound $4 \quad(87 \quad \mathrm{mg}, \quad 0.08 \quad \mathrm{mmol})$ and $2-(5$, 6-difluoro-3-oxo-2,3-dihydro-1H-inden-1-ylidene) malononitrile (0.16 g, $0.7 \mathrm{mmol})$ in $\mathrm{CHCl}_{3}$ $(30 \mathrm{~mL})$ was added pyridine $(0.5 \mathrm{~mL})$ under argon. The mixture was refluxed for $16 \mathrm{~h}$. After cooling to room temperature, the mixture was poured into methanol and filtered. The residue was purified by column chromatography using PE/ DCM (1:1) as eluent, yielding Y6Se as dark blue solid (58 mg, 48\%). ${ }^{1} \mathrm{H}$ NMR $\left(300 \mathrm{MHz} \mathrm{CDCl}_{3}\right) \delta 9.14(\mathrm{~s}, 2 \mathrm{H}), 8.56(\mathrm{dd}, J=9.9$, $6.5 \mathrm{~Hz}, 2 \mathrm{H}), 7.71(\mathrm{t}, J=7.6 \mathrm{~Hz}, 2 \mathrm{H}), 4.73(\mathrm{~d}, J=6.8 \mathrm{~Hz}, 4 \mathrm{H}), 3.22(\mathrm{t}, J=7.4 \mathrm{~Hz}, 4 \mathrm{H}), 2.11(\mathrm{~s}$, $2 \mathrm{H}), 1.86(\mathrm{~d}, J=6.7 \mathrm{~Hz}, 4 \mathrm{H}), 1.31-0.91(\mathrm{~m}, 48 \mathrm{H}), 0.72(\mathrm{~s}, 12 \mathrm{H}), 0.72-0.57(\mathrm{~m}, 6 \mathrm{H}) .{ }^{13} \mathrm{C}$ NMR (75 MHz, $\left.\mathrm{CDCl}_{3}\right) \delta 186.32$ - $186.06(\mathrm{~m}), 184.65$ - $184.39(\mathrm{~m}), 158.97$ - $158.71(\mathrm{~m})$, 
$153.96(\mathrm{~s}), 153.10(\mathrm{~s}), 145.25(\mathrm{~s}), 135.24(\mathrm{~s}), 137.60$ - $132.20(\mathrm{~m}), 135.85-132.20(\mathrm{~m})$, $133.94(\mathrm{~s}), 133.15(\mathrm{~s}), 131.52$ (s), $119.96-119.70(\mathrm{~m}), 115.62(\mathrm{~s}), 115.11-114.85(\mathrm{~m})$, $114.59(\mathrm{~s}), 112.47-112.20(\mathrm{~m}), 100.12-99.85(\mathrm{~m}), 77.63-76.79(\mathrm{~m}), 76.59$ (s), $68.72-$ $68.46(\mathrm{~m}), 55.70-55.44(\mathrm{~m}), 40.40(\mathrm{~s}), 31.92(\mathrm{~s}), 31.22(\mathrm{~s}), 31.17-29.02(\mathrm{~m}), 27.81-27.54$ (m), $22.77(\mathrm{~d}, J=12.1 \mathrm{~Hz}), 14.12(\mathrm{~s}), 13.88-7.15(\mathrm{~m})$. MS (MALDI-TOF) m/z calcd. for $\left(\mathrm{C}_{82} \mathrm{H}_{86} \mathrm{~F}_{4} \mathrm{~N}_{8} \mathrm{O}_{2} \mathrm{~S} \mathrm{~S}_{4} \mathrm{Se}\right):$ 1498.49. Found: 1499.0.

\section{Characterization}

\section{Measurements and Instruments}

${ }^{1} \mathrm{H}$ NMR and ${ }^{13} \mathrm{C}$ NMR spectra were recorded on Bruker AVANCE $300 \mathrm{MHz}$ or Bruker AVANCE $400 \mathrm{MHz}$ spectrometer at room temperature. The MALDI-TOF mass spectrometry experiments were performed on an autoflex III instrument (Bruker Daltonics, Inc.).

Cyclic voltammogram (CV) measurements were conducted on a CHI660C electrochemical workstation using sample film coated Platinum disk electrode as the working electrode, $\mathrm{Pt}$ wire as the counter electrode, and $\mathrm{Ag} / \mathrm{AgCl}$ as the reference electrode in a $0.1 \mathrm{M}$ tetrabutylammonium hexafluorophosphate acetonitrile solution. $\mathrm{Fc} / \mathrm{Fc}^{+}$redox couple was used as the inner reference for the calculation of the electronic energy levels of the Y6 and Y6Se.

UV-vis absorption spectra were measured on a UH4150 Spectrophotometer. Atomic force microscopy (AFM) images were recorded using a Digital Instruments Nano scope IIIa multimode atomic force microscope in tapping mode under ambient conditions.

Electroluminescence (EL) and electroluminescence quantum efficiency $\left(\mathrm{EQE}_{\mathrm{EL}}\right)$ measurements were performed by an integrated system (REPS, Enli Technology Co., Ltd.). $\mathrm{EQE}_{\mathrm{EL}}$ measurements were carried out from 1 to $4 \mathrm{~V}$. 
Fourier-transform photocurrent spectroscopy external quantum efficiency (FTPS-EQE) was measured by an integrated system (PECT-600, Enli Technology Co., Ltd.), where the photocurrent was amplified and modulated by a lock-in instrument.

Density functional theory (DFT) analysis with the B3LYP/6-31G (d, p) basis set was performed, in which all alkyl side chains of Y6Se were replaced by methyl groups. ${ }^{2}$

Space charge limited current (SCLC) method $^{3}$ : Electron-only devices were fabricated using the architectures: ITO/ZnO/Y6 or Y6Se/PDINN/Al. Y6 or Y6Se solution (in chloroform, $20 \mathrm{mg} \mathrm{mL}^{-1}$ ) was spin-coated (2000 rpm) and PDINN solution (in $\mathrm{MeOH}, 1 \mathrm{mg} \mathrm{mL}^{-1}$ ) was spin-coated (4000 rpm) sequentially on ITO/ZnO. Al electrode was slowly evaporated onto the surface of the underneath layer under vacuum $\left(\mathrm{ca} \cdot 10^{-5} \mathrm{~Pa}\right)$. The result was plotted as $J^{0.5}$ - $V$ curve and electron mobility $\left(\mu_{\mathrm{e}}\right)$ was calculated by the equation: $J=9 \varepsilon_{0} \varepsilon_{\mathrm{r}} \mu_{\mathrm{e}} V^{2} / 8 L^{3}$, where $L$ stands for the film thickness of the active layer $(\mathrm{ca} .100 \mathrm{~nm}), \varepsilon_{\mathrm{r}}$ is the relative dielectric constant of the transport medium, $\varepsilon_{0}$ the permittivity of free space, $J$ is current density and $V$ is the applied voltage.

GIWAXS measurements were accomplished with a Xeuss 2.0 SAXS/WAXS laboratory beamline using a $\mathrm{Cu}$ X-ray source $(8.05 \mathrm{keV}, 1.54 \AA$ ) and a Pilatus3R $300 \mathrm{~K}$ detector. The incidence angle is $0.2^{\circ}$. GIWAXS samples are prepared on silicon substrate by spin coating.

\section{Fabrication and Characterization of OFETs}

OFET devices were fabricated on a commercial $\mathrm{Si} / \mathrm{SiO}_{2} / \mathrm{Au}$ substrate purchased from First MEMS Co. Ltd. A heavily doped n-type Si wafer and a layer of dry oxidized $\mathrm{SiO}_{2}(300$ $\mathrm{nm}$, with roughness lower than $0.1 \mathrm{~nm}$ and capacitance of $11 \mathrm{nF} \mathrm{cm}$ ch $^{-2}$ ) were used as a gate electrode and gate dielectric layer, respectively. The drain-source (D-S) gold contacts were 
fabricated by photolithography. Before deposition of the organic semiconductor, the gate dielectrics were treated with octadecyltrichlorosilane (OTS) in a vacuum oven at a temperature of $120{ }^{\circ} \mathrm{C}$, forming an OTS self-assembled monolayers. The treated substrates were rinsed successively with hexane, chloroform, and isopropyl alcohol. Y6Se or Y6 neat film were spin coated on the substrate at $1500 \mathrm{rpm}$ for 30s from chloroform solution with the concentration of $15 \mathrm{mg} \mathrm{mL}$. The devices were measured on a Keithley $4200 \mathrm{SCS}$ semiconductor parameter analyzer at room temperature. The mobilities were calculated from the saturation region with the following equation: $I_{\mathrm{D}}{ }^{0.5}=\left(C_{\mathrm{i}} \mu W / 2 L\right)^{0.5}\left(V_{\mathrm{G}}-V_{\mathrm{T}}\right)$ where $I_{\mathrm{D}}$ is the drain-source current, $W$ is the channel width $(1400 \mu \mathrm{m}), L$ is the channel length $(10 \mu \mathrm{m}), \mu$ is the field-effect mobility, $C_{\mathrm{i}}$ is the capacitance per unit area of the gate dielectric layer, and $V_{\mathrm{G}}$ and $V_{\mathrm{T}}$ are the gate voltage and threshold voltage, respectively.

\section{Fabrication and Characterization of OSCs}

OSCs were fabricated with the structure of ITO/PEDOT:PSS/D18:Y6Se or Y6/ PNDIT-F3N-Br/Ag. A PEDOT:PSS (10 nm) layer was deposited through spin-coating on precleaned ITO-coated glass and dried subsequently at $150{ }^{\circ} \mathrm{C}$ for $15 \mathrm{~min}$ in air. Then the device was transferred to a nitrogen glove box, where the active blend layer was spin-coated from chloroform solution containing a blend of D18: Y6Se or Y6 at $2000 \mathrm{rpm}$ for $30 \mathrm{~s}$ onto the PEDOT: PSS layer. The concentration of D18 in solution is $4 \mathrm{mg} \mathrm{mL}^{-1}$. The PNDIT-F3N-Br solution $\left(0.5 \mathrm{mg} \mathrm{mL}^{-1}\right.$ in methanol with $0.5 \%$ acetic acid $)$ was spin-coated on the active layer at $2000 \mathrm{rpm}$ for $30 \mathrm{~s}$. Finally, Ag electrode (ca. $120 \mathrm{~nm}$ ) was slowly evaporated onto the surface of the underneath layer under vacuum $\left(c a .10^{-5} \mathrm{~Pa}\right)$. The active area of the cells was $0.040 \mathrm{~cm}^{2}$. The devices based on neat $\mathrm{Y} 6$ or Y6Se film for EL and 
FTPS-EQE tests were prepared by the same procedure for OSCs, and the active layer Y6Se or Y6 neat film were spin coated on the substrate at $1500 \mathrm{rpm}$ for $30 \mathrm{~s}$ from chloroform solution with the concentration of $15 \mathrm{mg} \mathrm{mL} \mathrm{m}^{-1}$. The $J-V$ curves were measured under AM1.5G illumination at $100 \mathrm{~mW} \mathrm{~cm}^{-2}$ using an AAA solar simulator (XES-70S1, SAN-EI Electric Co., Ltd) calibrated with a standard photovoltaic cell equipped with a KG5 filter (certificated by the National Institute of Metrology) and a Keithley 2450 source-measure unit. The EQE data were obtained using a solar cell spectral response measurement system (QE-R3011, Enli Technology Co. Ltd). 


\section{Additional Tables and Figures}

Table S1. Device parameters of solar cells based on D18: Y6Se with different weight ratio. Average PCEs for 8 devices in brackets.

\begin{tabular}{ccccc}
\hline D18: Y6Se $(w / w)$ & $V_{\mathrm{OC}}(\mathrm{V})$ & $J_{\mathrm{SC}}\left(\mathrm{mA} / \mathrm{cm}^{2}\right)$ & $\mathrm{FF}$ & $\mathrm{PCE}(\%)$ \\
\hline $1: 1$ & 0.835 & 27.46 & 0.738 & $16.9(16.7)$ \\
$1: 1.3$ & 0.837 & 27.55 & 0.749 & $17.3(17.2)$ \\
$1: 1.6$ & 0.839 & 27.98 & 0.753 & $17.7(17.5)$ \\
$1: 2$ & 0.842 & 27.06 & 0.752 & $17.1(16.9)$ \\
\hline
\end{tabular}
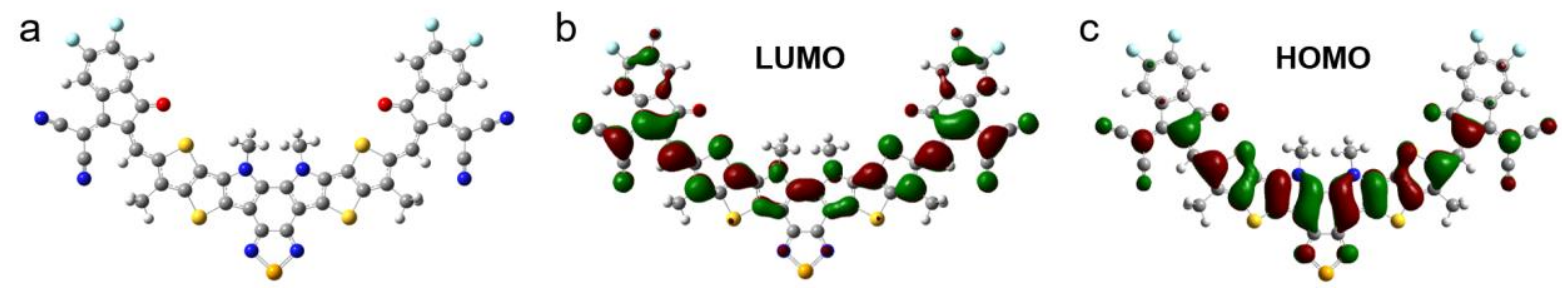

Figure S1. Theoretically optimized geometry (a) and corresponding electronic structures (b, c) of Y6Se, in which all alkyl side chains were replaced by methyl groups. 


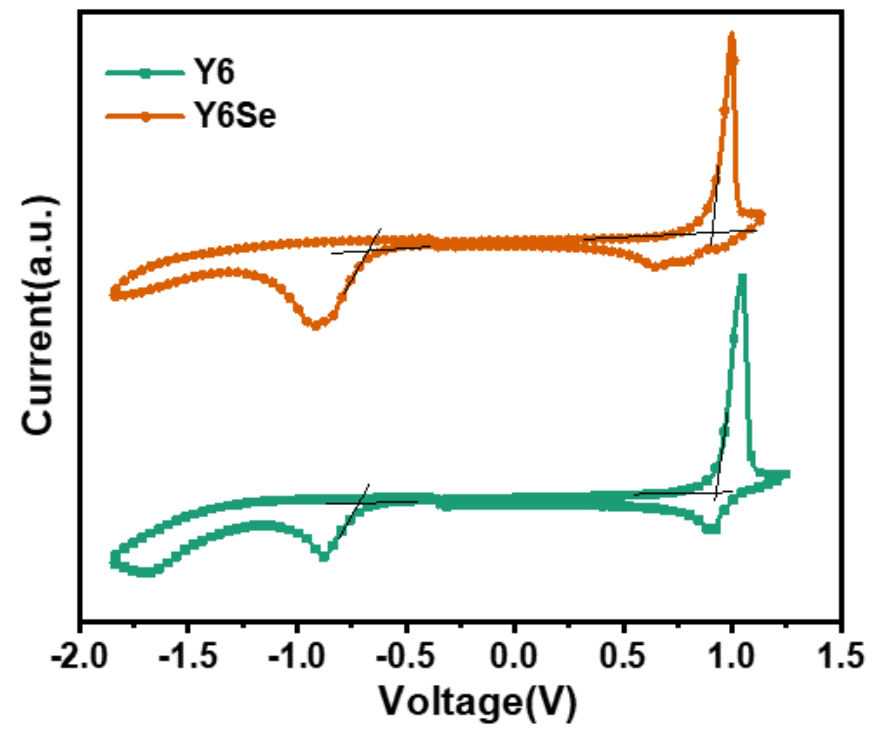

Figure S2. Cyclic voltammogram of Y6Se and Y6 thin film. Potential vs. Fc/Fc ${ }^{+}$. 
a

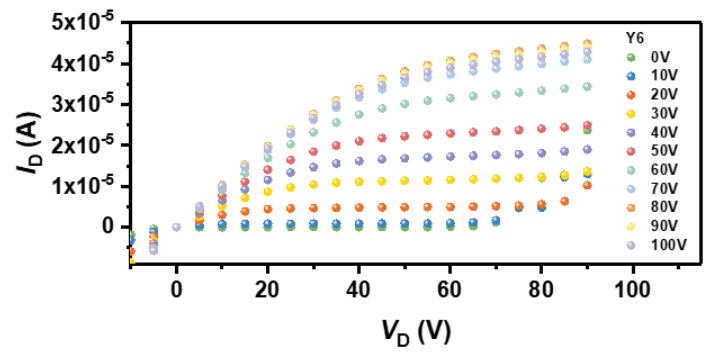

b

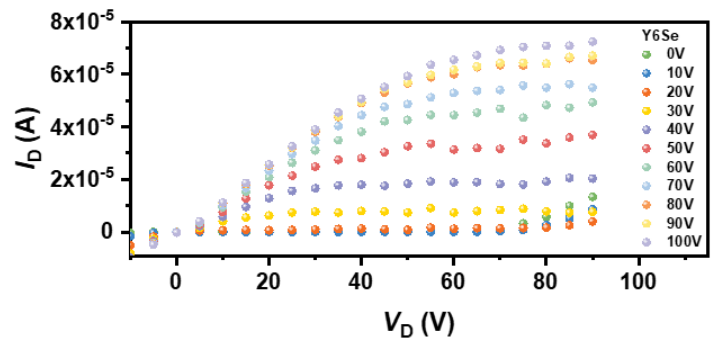

C

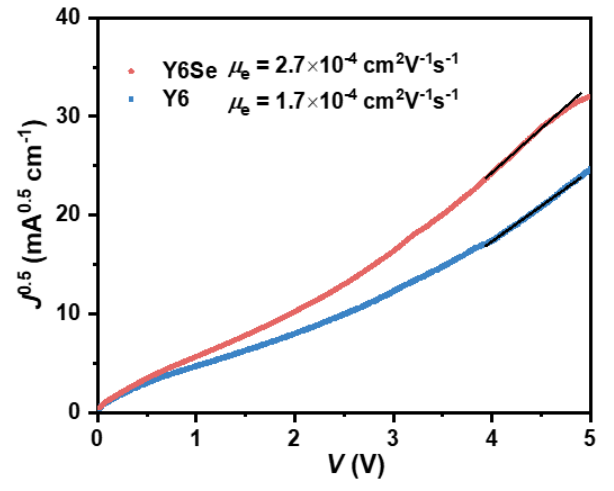

Figure S3. (a) Output curves of Y6 obtained from OFET devices. (b) Output curves of Y6Se obtained from OFET devices. (c) $J^{0.5}-V$ plots for electron-only devices based on neat Y6 film and Y6Se film. 

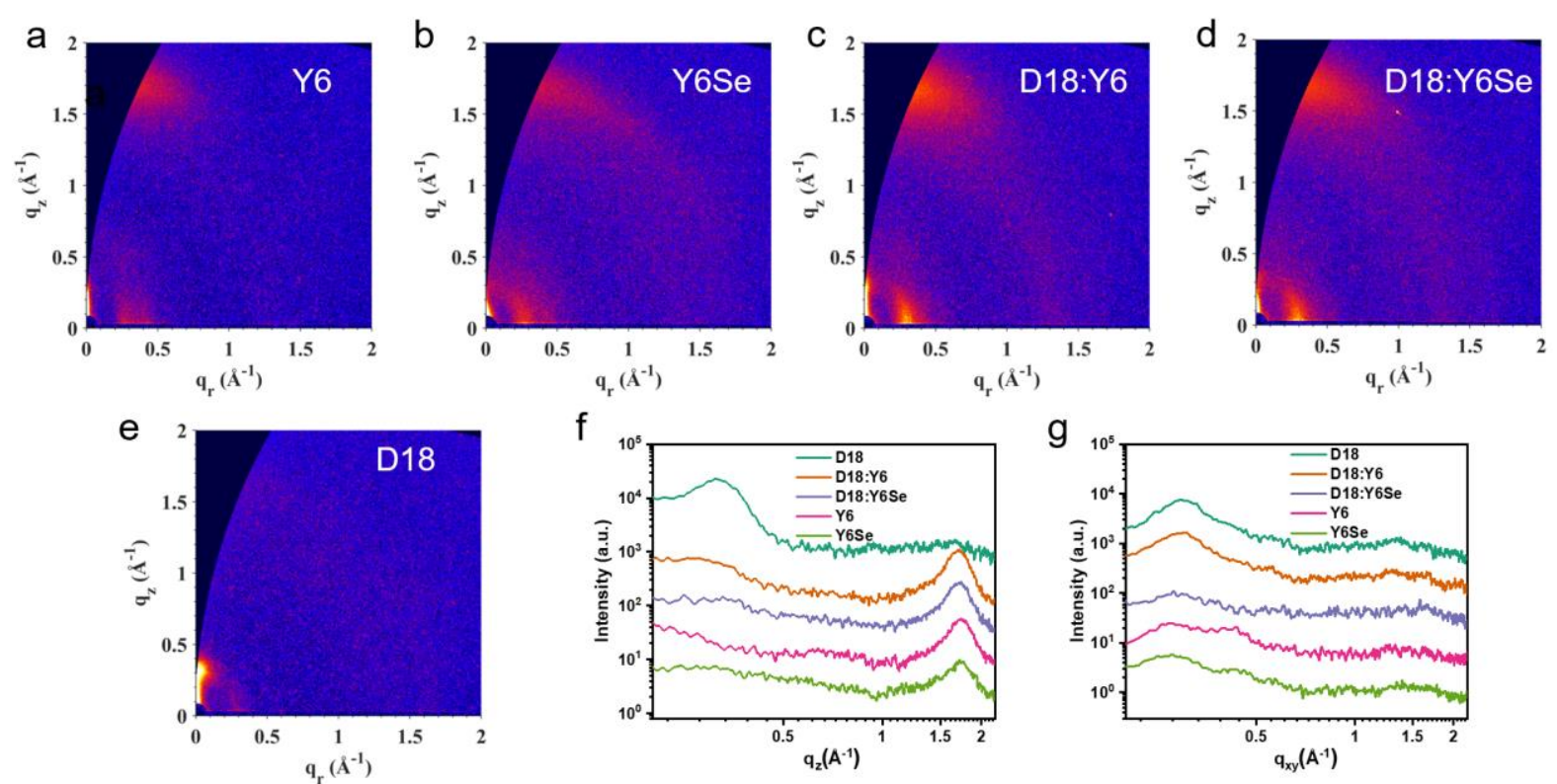

Figure S4. GIWAXS images of neat Y6 (a), neat Y6Se (b), blended D18:Y6 (c), blended D18:Y6Se (d), neat D18 (e). GIWAXS intensity profiles along the out-of-plane (f) and in-plane $(\mathrm{g})$ directions. 


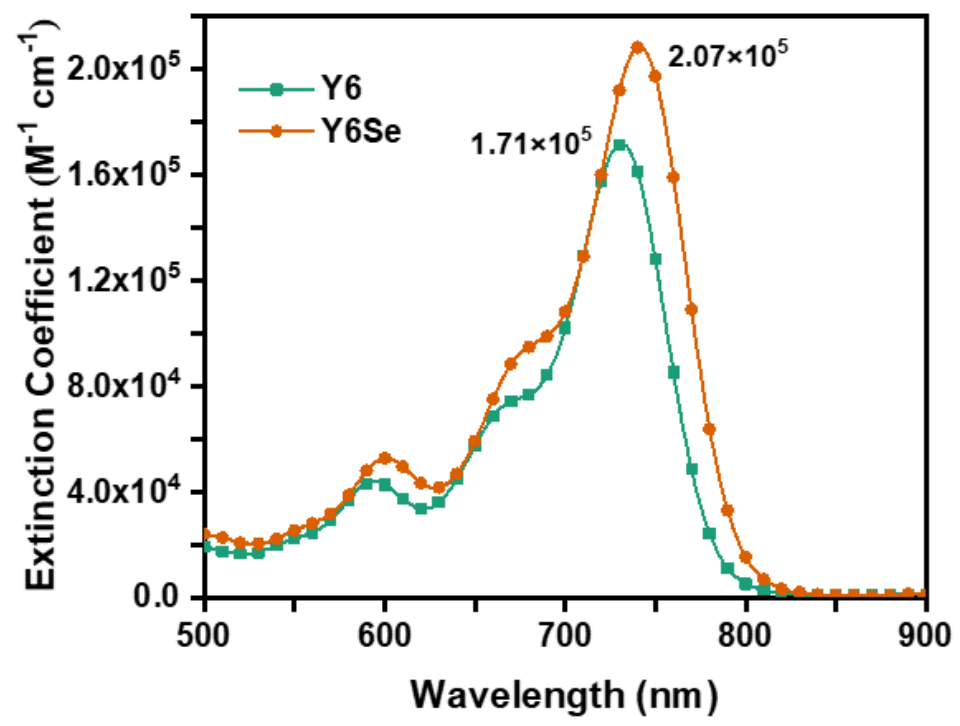

Figure S5. Extinction coefficient spectra of $\mathrm{Y} 6 \mathrm{Se}$ and $\mathrm{Y} 6$ in $\mathrm{CHCl}_{3}$ solution. 

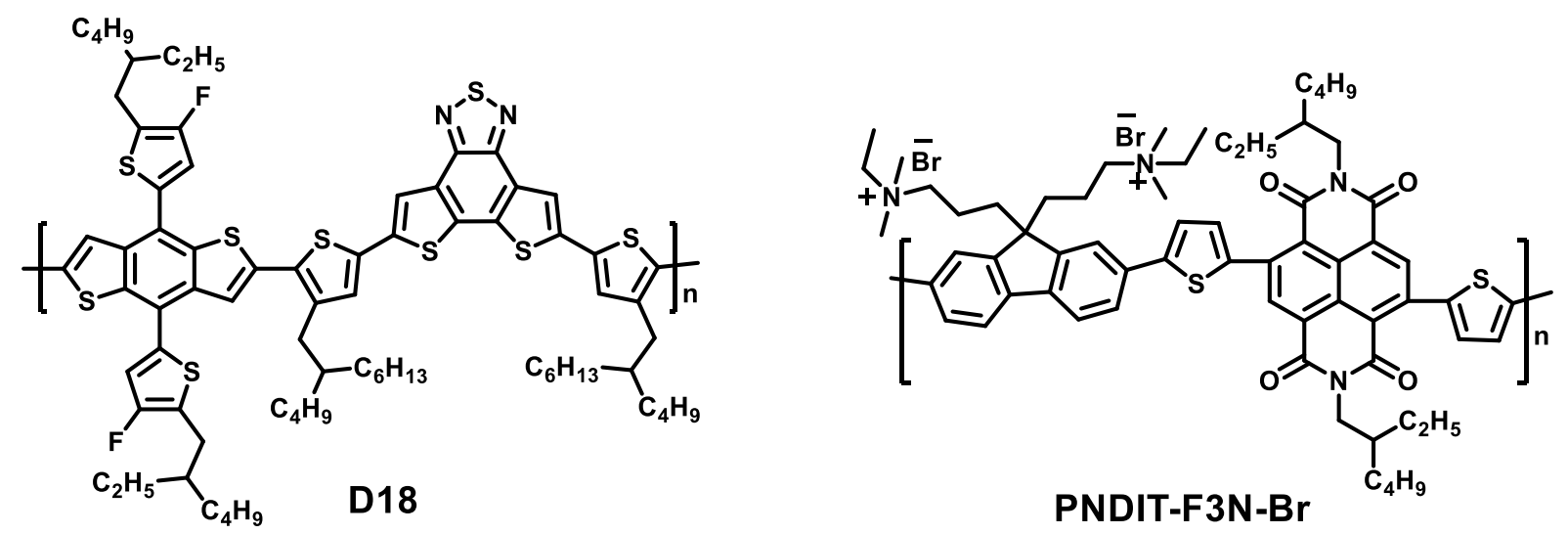

Figure S6. Chemical structures of D18 and PNDIT-F3N-Br used in organic solar cell devices. 

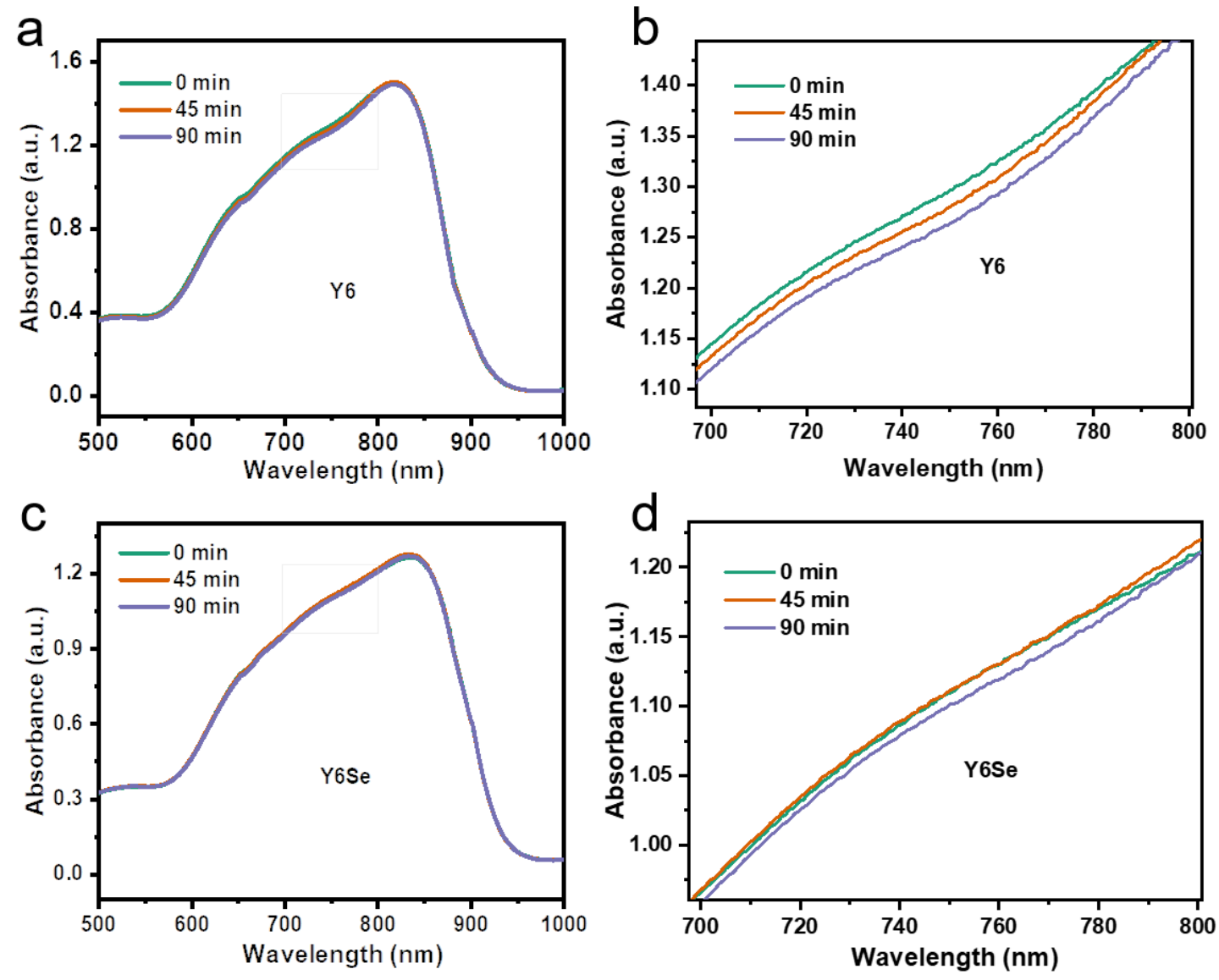

Figure S7. Absorption spectra of the Y6 film (a) and Y6Se film (c) under illumination at strong ultraviolet A (UVA) 340 light with a $12 \mathrm{~mW} \mathrm{~cm}^{-2}$ with different illuminating time. Zoom in images of absorption spectra of Y6 film (b) and Y6Se film (d) at the range from 700 $\mathrm{nm}$ to $800 \mathrm{~nm}$. 


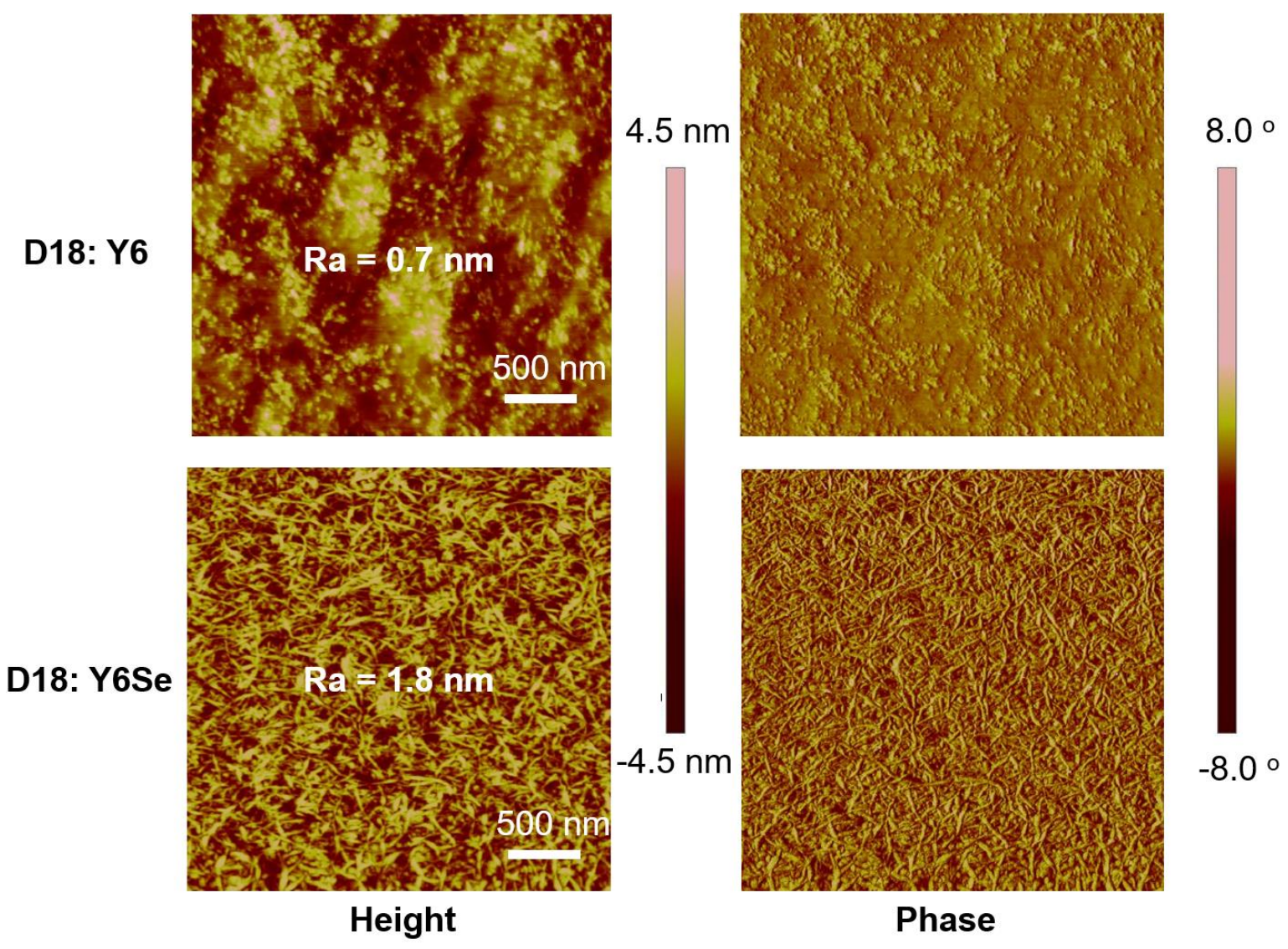

Figure S8. AFM height and phase images of as cast D18:Y6 and D18: Y6Se blended film. 

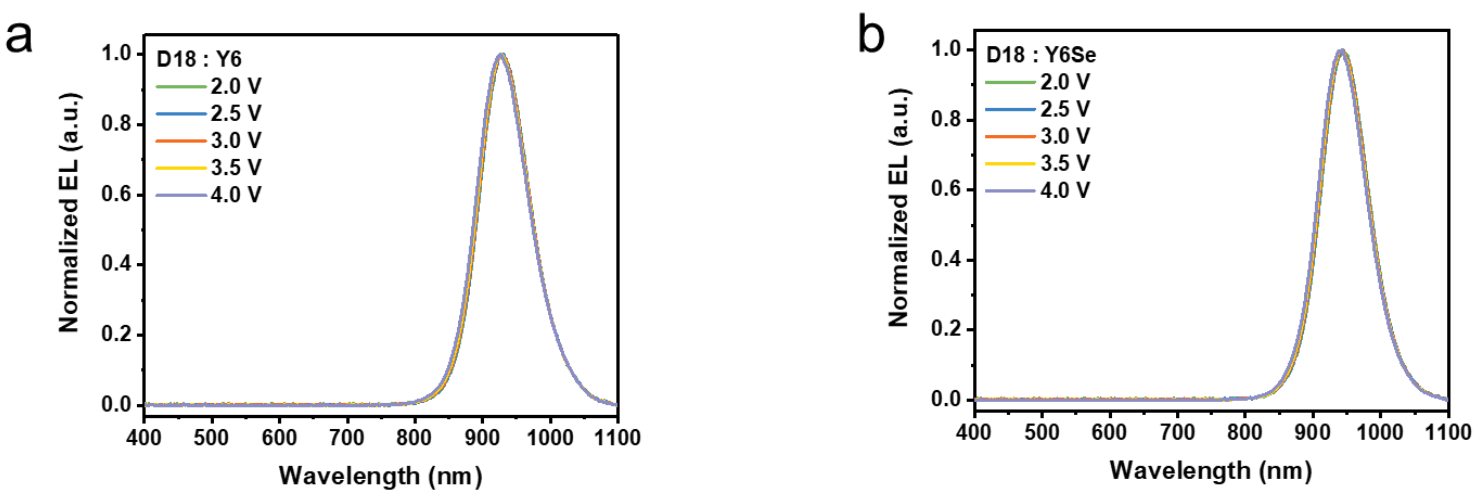

Figure S9. (a) Normalized EL spectra from the devices of D18:Y6 blended film with different injection voltage. (b) Normalized EL spectra from the devices of D18: Y6Se blended film with different injection voltage. 


\section{Spectral Charts of NMR and MS}

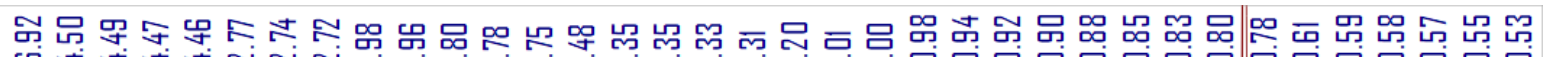

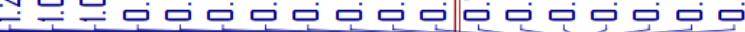

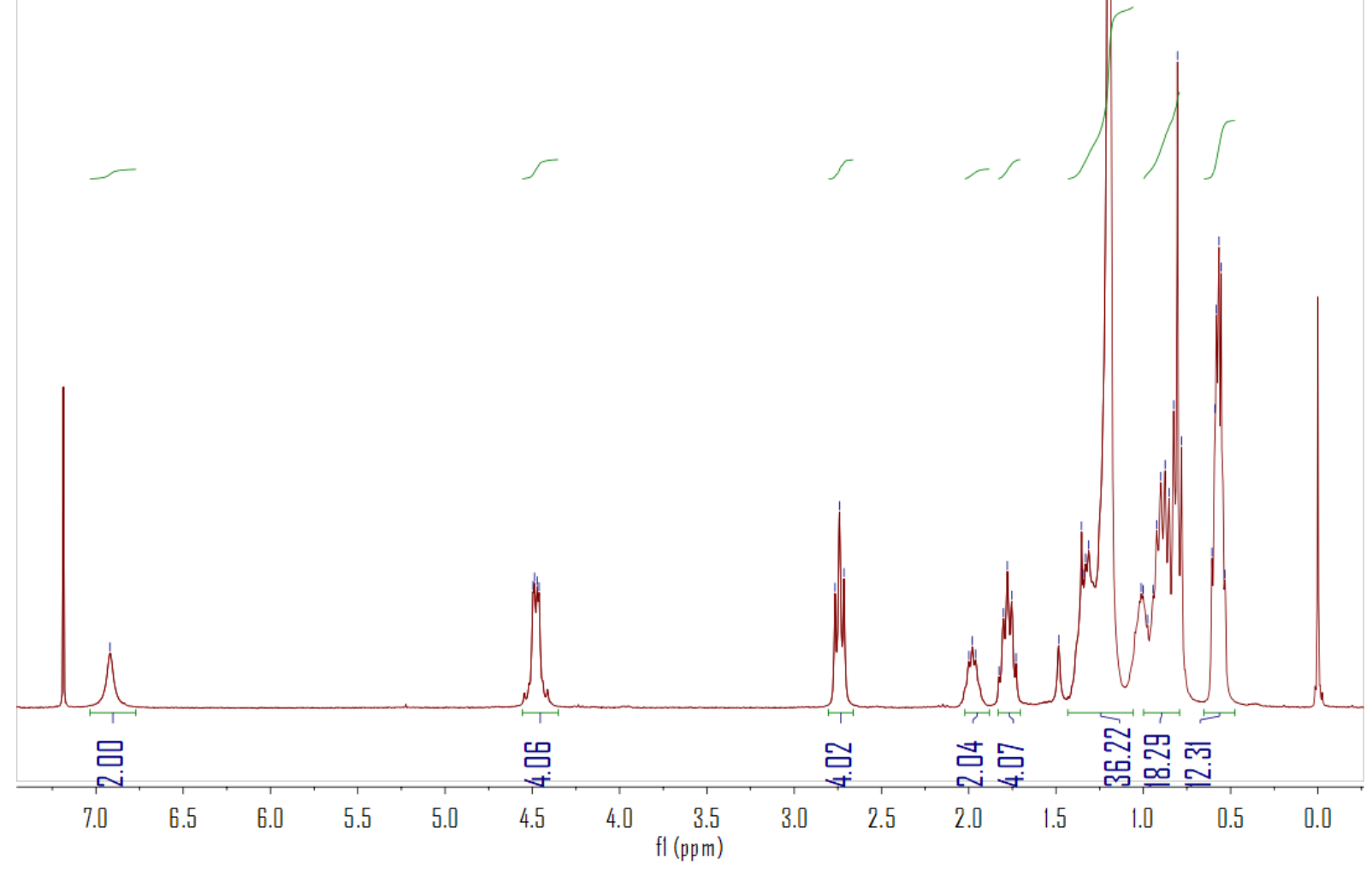

Figure S10. ${ }^{1} \mathrm{H}$ NMR spectrum of compound 3 in $\mathrm{CDCl}_{3}$. 


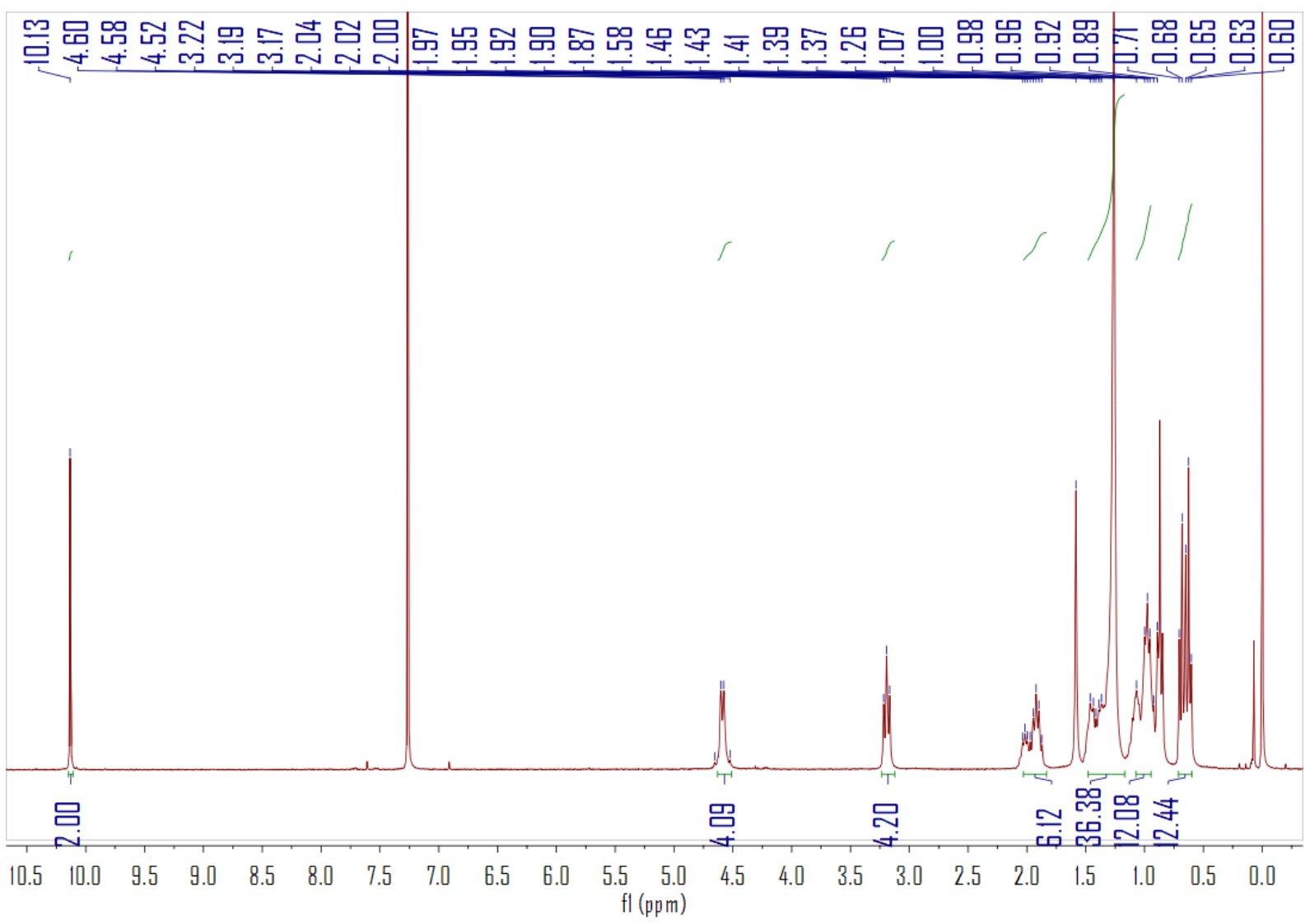

Figure S11. ${ }^{1} \mathrm{H}$ NMR spectrum of compound 4 in $\mathrm{CDCl}_{3}$. 


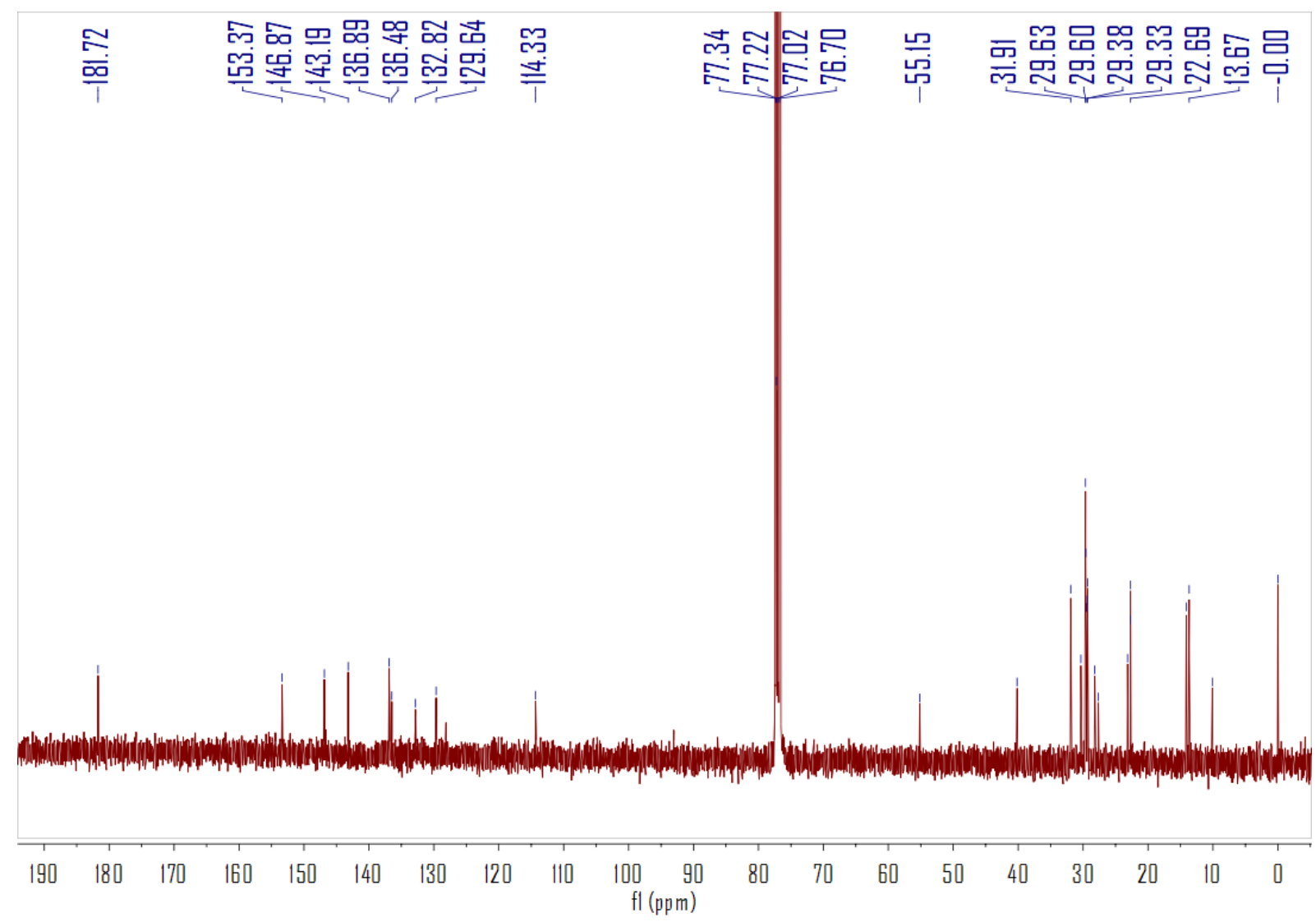

Figure S12. ${ }^{13} \mathrm{C}$ NMR spectrum of compound 4 in $\mathrm{CDCl}_{3}$. 


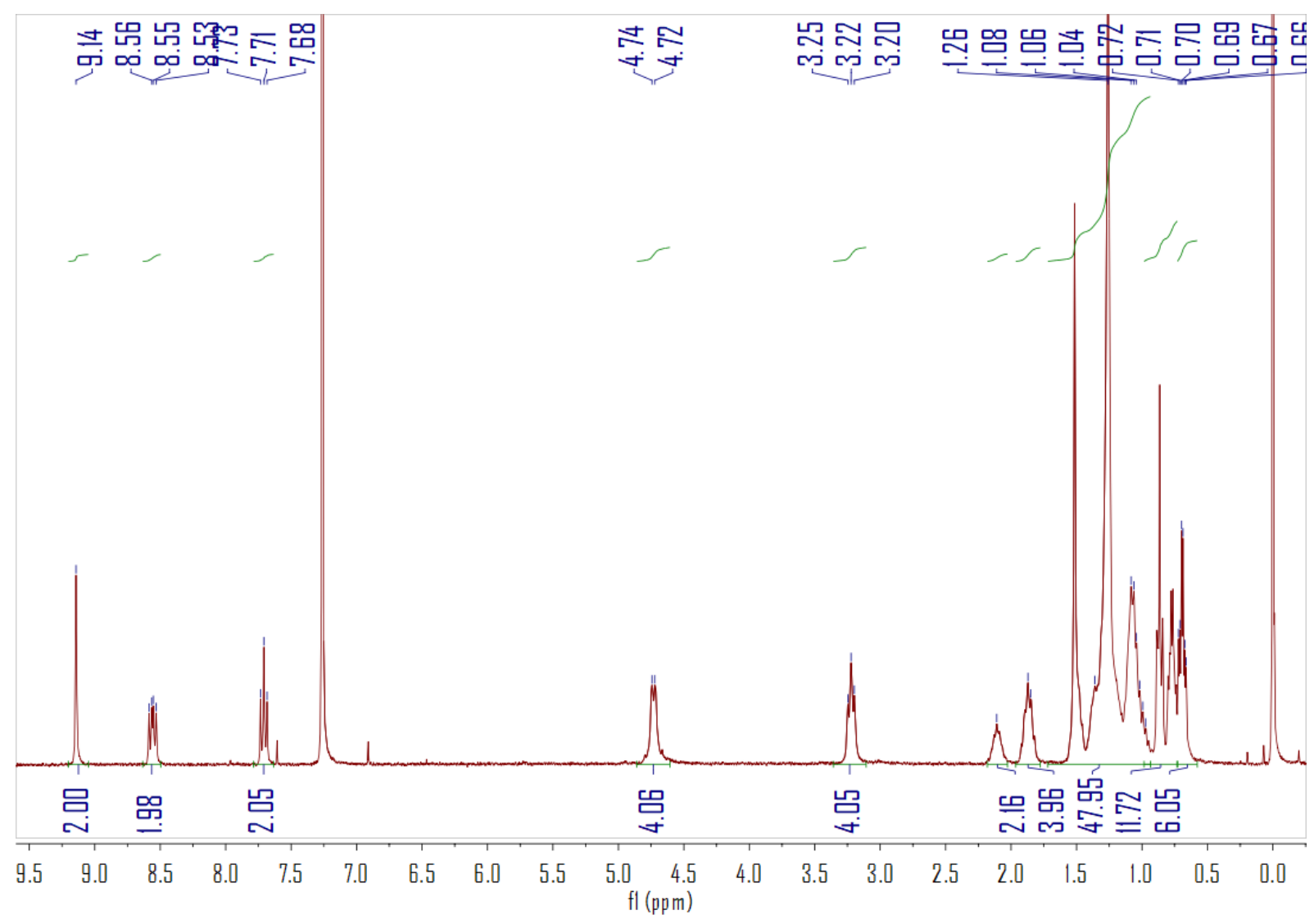

Figure S13. ${ }^{1} \mathrm{H}$ NMR spectrum of compound $\mathrm{Y} 6 \mathrm{Se}$ in $\mathrm{CDCl}_{3}$. 

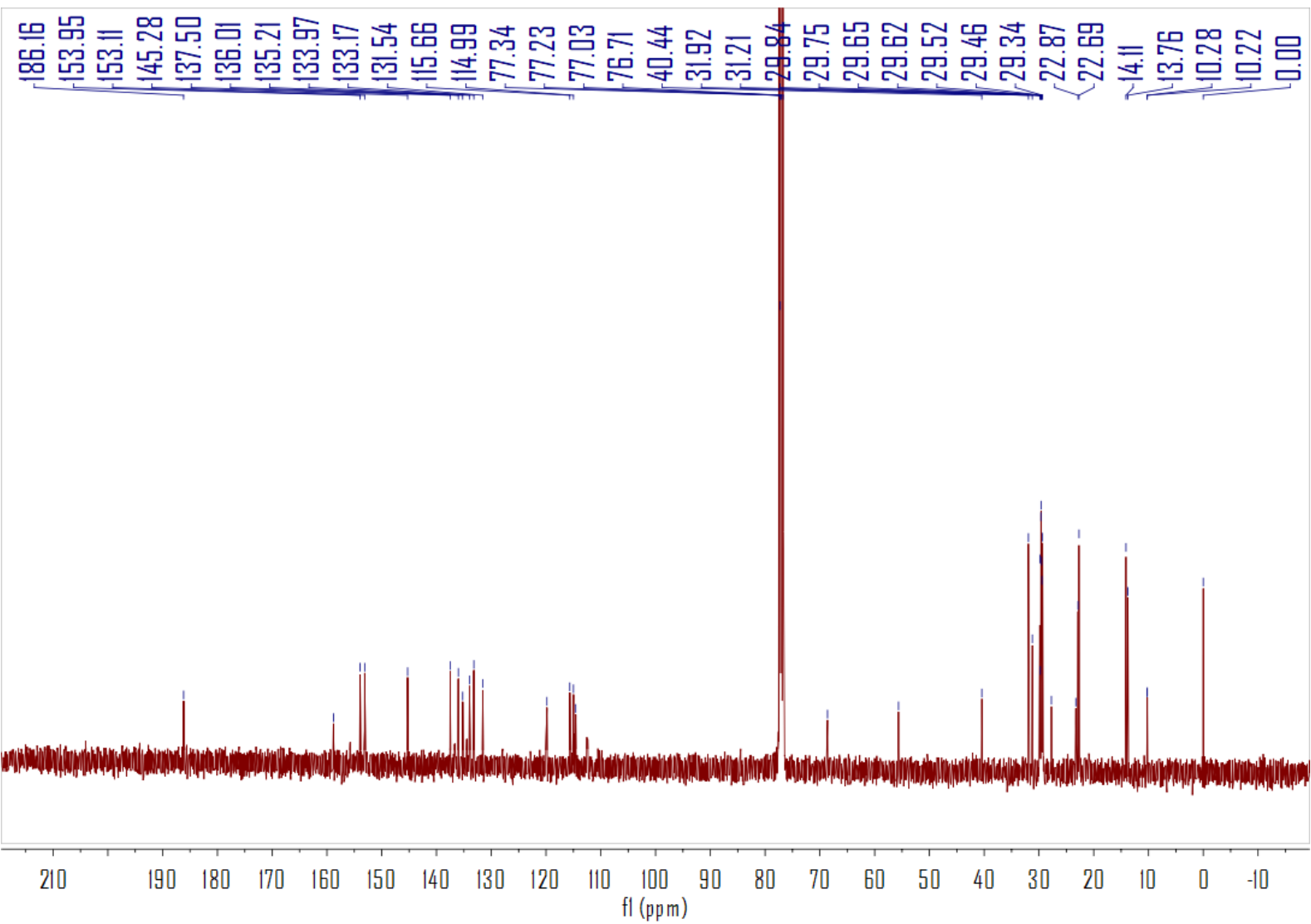

Figure S14. ${ }^{13} \mathrm{C}$ NMR spectrum of compound $\mathrm{Y} 6 \mathrm{Se}$ in $\mathrm{CDCl}_{3}$. 


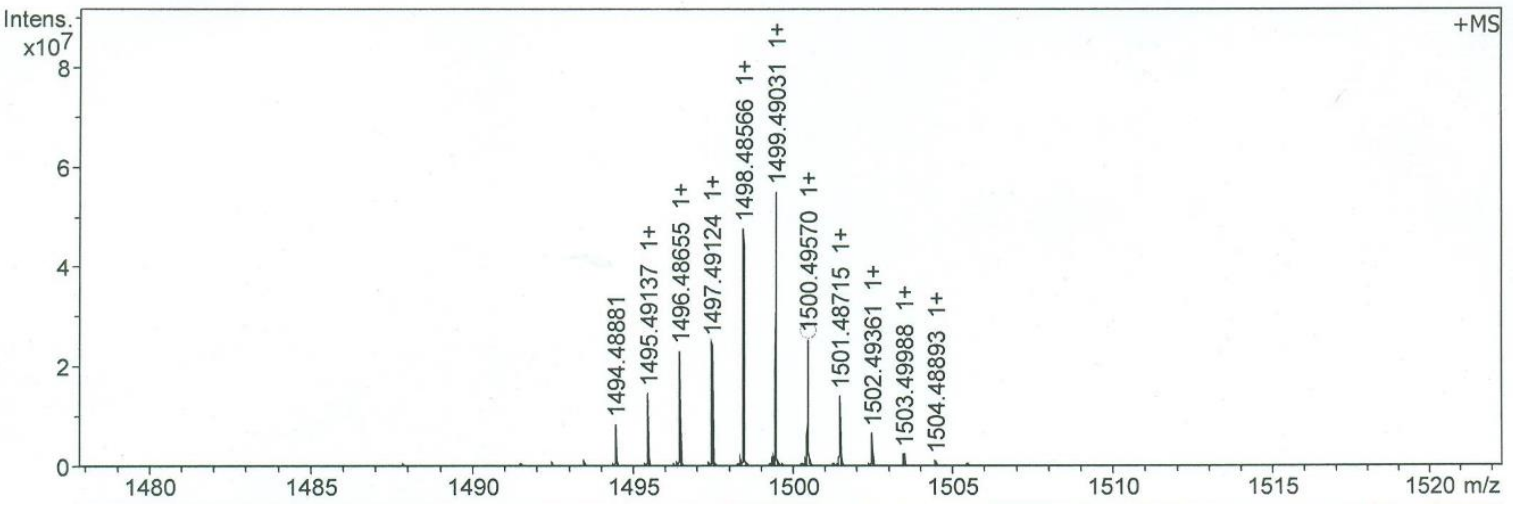

Figure S15. The high resolution mass spectrum (MALDI-TOF) of Y6Se. 


\section{REFERENCES}

1. Yao, J.; Qiu, B.; Zhang, Z. G.; Xue, L.; Wang, R.; Zhang, C.; Chen, S.; Zhou, Q.; Sun, C.; Yang, C.; Xiao, M.; Meng, L.; Li, Y., Cathode engineering with perylene-diimide interlayer enabling over $17 \%$ efficiency single-junction organic solar cells. Nat. Commun. 2020, 11, 2726.

2. Frisch, M. J.; Trucks, G. W.; Schlegel, H. B.; Scuseria, G. E.; Robb, M. A.; Cheeseman, J. R.; Scalmani, G.; Barone, V.; Mennucci, B.; Petersson, G. A.; Nakatsuji, H.; Caricato, M.; Li, X.; Hratchian, H. P.; Izmaylov, A. F.; Bloino, J.; Zheng, G.; Sonnenberg, J. L.; Hada, M.; Ehara, M.; Toyota, K.; Fukuda, R.; Hasegawa, J.; Ishida, M.; Nakajima, T.; Honda, Y.; Kitao, O.; Nakai, H.; Vreven, T.; Montgomery, J. A., Jr.; Peralta, J. E.; Ogliaro, F.; Bearpark, M.; Heyd, J. J.; Brothers, E.; Kudin, K. N.; Staroverov, V. N.; Kobayashi, R.; Normand, J.; Raghavachari, K.; Rendell, A.; Burant, J. C.; Iyengar, S. S.; Tomasi, J.; Cossi, M.; Rega, N.; Millam, J. M.; Klene, M.; Knox, J. E.; Cross, J. B.; Bakken, V.; Adamo, C.; Jaramillo, J.; Gomperts, R.; Stratmann, R. E.; Yazyev, O.; Austin, A. J.; Cammi, R.; Pomelli, C.; Ochterski, J. W.; Martin, R. L.; Morokuma, K.; Zakrzewski, V. G.; Voth, G. A.; Salvador, P.; Dannenberg, J. J.; Dapprich, S.; Daniels, A. D.; Farkas, Ö.; Foresman, J. B.; Ortiz, J. V.; Cioslowski, J.; Fox, D. J. Gaussian 16, Revision A.03, Gaussian, Inc., Wallingford CT, 2016.

3. Malliaras, G. G.; Salem, J. R.; Brock, P. J.; Scott, C., Electrical characteristics and efficiency of single-layer organic light-emitting diodes. Phys. Rev. B 1998, 58, 13411-13414. 